\title{
MLL3/MLL4/COMPASS Family on Epigenetic Regulation of Enhancer Function and Cancer
}

\author{
Christie C. Sze and Ali Shilatifard \\ Department of Biochemistry and Molecular Genetics and Robert H. Lurie NCl Comprehensive Cancer \\ Center, Northwestern University Feinberg School of Medicine, Chicago, Illinois 60611 \\ Correspondence: ash@northwestern.edu
}

\begin{abstract}
During development, precise spatiotemporal patterns of gene expression are coordinately controlled by cis-regulatory modules known as enhancers. Their crucial role in development helped spur numerous studies aiming to elucidate the functional properties of enhancers within their physiological and disease contexts. In recent years, the role of enhancer malfunction in tissue-specific tumorigenesis is increasingly investigated. Here, we direct our focus to two primary players in enhancer regulation and their role in cancer pathogenesis: MLL3 and MLL4, members of the COMPASS family of histone H3 lysine 4 (H3K4) methyltransferases, and their complex-specific subunit UTX, a histone H3 lysine 27 (H3K27) demethylase. We review the most recent evidence on the underlying roles of MLL3/MLL4 and UTX in cancer and highlight key outstanding questions to help drive future research and contribute to our fundamental understanding of cancer and facilitate identification of therapeutic opportunities.
\end{abstract}

Enhancers are noncoding DNA regulatory seEquences that govern the complex spatiotemporal patterns of gene expression throughout development by heightening the rate of transcription of target genes (Banerji et al. 1981; Smith and Shilatifard 2014). These DNA elements can span several hundred base pairs (bp) to a few kilobases $(\mathrm{kb})$ and contain arrays of short DNA modules that serve as binding sites for sequence-specific transcription factors, which recruit a combination of factors that together dictate the function of the enhancer (Maniatis et al. 1987). A key attribute of enhancers is that they act independently of orientation and distance to their target promoter(s), and are littered throughout the genome within intragenic and intergenic regions (Smith and Shila- tifard 2014). Despite several decades of extensive research, the precise mechanism of action of enhancers is still poorly understood. Studies have shown that enhancers can exert their activity over long distances, bypassing neighboring genes, and communicate with a specific distal promoter (Blackwood and Kadonaga 1998; Bulger and Groudine 2011; Levine et al. 2014). Such enhancer-promoter communication is established via a looping mechanism mediated by the cohesin and mediator complexes and other associated proteins (Dorsett 1999; Kagey et al. 2010; Dorsett and Merkenschlager 2013).

The identification and functional annotation of enhancers in the metazoan genome have been challenging; however, the development of high-throughput sequencing in recent

Editors: Scott A. Armstrong, Steven Henikoff, and Christopher R. Vakoc

Additional Perspectives on Chromatin Deregulation in Cancer available at www.perspectivesinmedicine.org

Copyright (C) 2016 Cold Spring Harbor Laboratory Press; all rights reserved; doi: 10.1101/cshperspect.a026427 Cite this article as Cold Spring Harb Perspect Med 2016;6:a026427 
years has facilitated the discovery of tissue-specific enhancers. Genome-wide chromatin immunoprecipitation (ChIP) analyses of histone modifications led to the identification of chromatin signatures for enhancers. The epigenetic mark histone $\mathrm{H} 3$ lysine 4 (H3K4) monomethylation is particularly enriched on these regulatory elements, both active and inactive/poised (Heintzman et al. 2007, 2009; Smith and Shilatifard 2014). Additionally, the presence of acetylated histone $\mathrm{H} 3$ lysine 27 (H3K27ac) and trimethylated histone H3 lysine 27 (H3K27me) can further distinguish active from inactive enhancers, respectively (Creyghton et al. 2010; Rada-Iglesias et al. 2011; Zentner et al. 2011; Smith and Shilatifard 2014).

Given their essential role in transcriptional regulation and gene expression, it is not surprising that disruption of enhancers can lead to disease. In recent years, the role of enhancer malfunction in tumorigenesis is increasingly studied (Akhtar-Zaidi et al. 2012; Kurdistani 2012; Sur et al. 2012; Aran et al. 2013; Loven et al. 2013; Herz et al. 2014; Morgan and Shilatifard 2015). In this review, we focus our attention on the proteins and factors that mediate changes in enhancer chromatin states and their role in cancer pathogenesis.

\section{THE COMPASS FAMILY OF HISTONE H3K4 METHYLASES}

The mixed lineage leukemia (MLL) gene was first discovered as an oncogenic fusion resulting from seemingly random translocations in patients with hematological malignancies (Ziemin-van der Poel et al. 1991; Djabali et al. 1992; Gu et al. 1992; Tkachuk et al. 1992; Shilatifard 2012). To investigate the role of MLL in leukemia, initial efforts were focused on isolating MLL-containing complexes to understand the fundamental biochemical properties, functions, and regulation of MLL under normal conditions. An ancestral homolog of MLL, Set1, was identified in the budding yeast Saccharomyces cerevisiae and was found to exist within a macromolecular complex named COMPASS (complex of proteins associated with Set1) (Miller et al. 2001; Roguev et al. 2001; Krogan et al. 2002). Set1, together with other subunits within COMPASS, is capable of catalyzing mono-, di-, and trimethylation on histone H3K4 in yeast (Schneider et al. 2005). Subsequent studies revealed a diverse family of COMPASS in metazoans. Although yeast only has a single Set1/COMPASS that can mediate all three H3K4 methylation patterns, Drosophila melanogaster has three $\mathrm{H} 3 \mathrm{~K} 4$ methyltransferases, named dSet1, trithorax (Trx), and trithorax-related (Trr) (Eissenberg and Shilatifard 2010; Mohan et al. 2011). For mammals, there are two paralogs corresponding to each of the three Drosophila members: Set1a (also known as KMT2F) and Set1b (or KMT2G), orthologous to dSet1; MLL1 (or KMT2A; GeneID 4297) and MLL2 (or KMT2B; GeneID 9757), orthologous to Trx; and MLL3 (or KMT2C; GeneID 58508) and MLL4 (or KMT2D; GeneID 8085), orthologous to Trr (Allis et al. 2007; Shilatifard 2012). The Drosophila and mammalian methylases also reside in COMPASS-like complexes, which were shown through ensuing studies to contain (1) core subunits critical for the enzymatic activity (Fig. 1, highlighted in dark blue), and (2) specific components that may confer functional uniqueness to each complex (Fig. 1, highlighted in green) (Mohan et al. 2011; Shilatifard 2012).

The methylase subunits of the COMPASS family all possess a catalytic 130-amino-acidlong carboxy-terminal motif called the SET domain, named after the Drosophila proteins $\underline{\mathrm{Su}}$ (var)3-9, enhancer of zeste $[\mathrm{E}(\mathrm{z})]$, and trithorax (Trx) (Tschiersch et al. 1994; Stassen et al. 1995). In contrast, regions amino-terminal to the SET domain differ across the family members. In brief, mammalian Setla and Set $1 b$ each have an amino-terminal RNA recognition motif (RRM) and an N-SET domain adjacent to the SET domain, whereas mammalian MLL1-4 methylases contain varying numbers of plant homeodomain (PHD) fingers, FYrich (FYR) domains, and DNA-binding motifs such as AT-hooks, high mobility group (HMG) boxes, and CXXC domains (Fig. 2) (Herz et al. 2013). The domain architectural variability across the methylases denotes the binding and functional diversity of the COMPASS family. 
Enhancer Chromatin and Disease

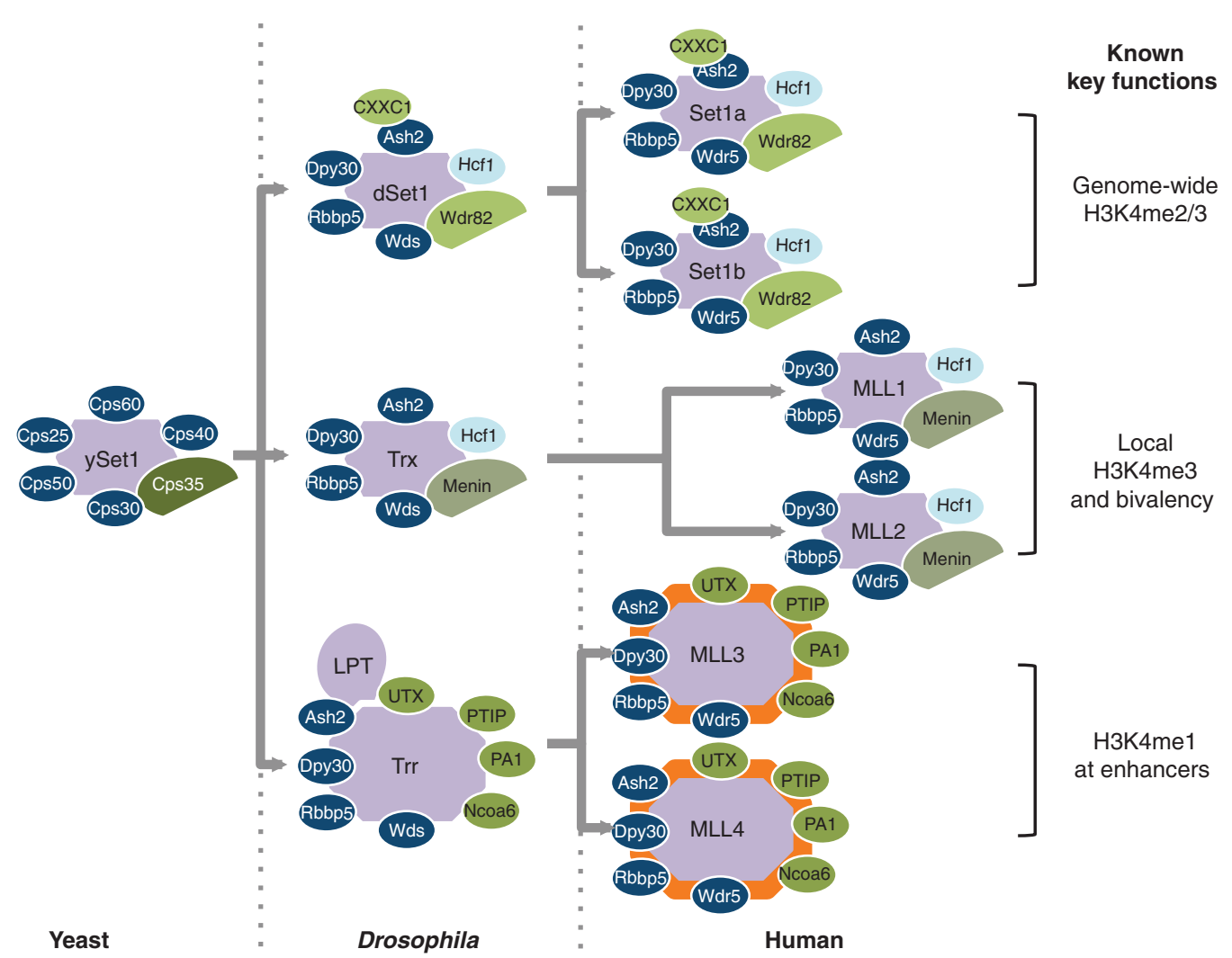

Figure 1. The COMPASS family of histone H3 lysine 4 (H3K4) methyltransferases in yeast, flies, and humans. In yeast, there is only one Set 1 methyltransferase capable of methylating histone H3K4. Flies have three COMPASS family members: dSet1, trithorax (Trx), and trithorax-related (Trr). Mammals have two paralogs for each of the three fly members for a total of six COMPASS members. Core subunits found in all COMPASS complexes are highlighted in dark blue, whereas subunits specific to the complex are marked in green. Hcfl (light blue) is reportedly specific to be in Set1 and Trx branches but not in the Trr complex (van Nuland et al. 2013). Mixed lineage leukemia (MLL)3 and MLL4, the focus of this review, are outlined in orange. Key functions known to date for each branch of COMPASS are noted.

\section{THE MLL3 AND MLL4/COMPASS FAMILY AS ENHANCER MONOMETHYLASES}

A growing body of evidence points to a model in which the responsibilities of $\mathrm{H} 3 \mathrm{~K} 4$ methylation are divided among the COMPASS family members to ensure proper transcriptional modulation. Several studies have shown that dSet1 and mammalian Setla/b are responsible for bulk $\mathrm{H} 3 \mathrm{~K} 4 \mathrm{di}$ - and trimethylation across the genome (Wu et al. 2008; Ardehali et al. 2011; Mohan et al. 2011; Hallson et al. 2012), whereas Trx and MLL1/MLL2 are necessary for gene-specific $\mathrm{H} 3 \mathrm{~K} 4$ trimethylation, including Hox gene promoters (Wang et al. 2009) and bivalent promoters (promoters marked by concurrent trimethylation of $\mathrm{H} 3 \mathrm{~K} 4$ and $\mathrm{H} 3 \mathrm{~K} 27$ and poised to express developmental genes) in mouse embryonic stem (mES) cells (Hu et al. 2013b). Trx was initially discovered as a regulator of the developmental expression of Hox genes in Drosophila, specifically being required for maintaining Hox gene activation (Breen and Harte 1991; Pirrotta 1998; Mahmoudi and Verrijzer 2001; Poux et al. 2002; Klymenko and Muller 2004; Shilatifard 2012). It is through shared protein homology with Trx that Trr was cloned (Sedkov et al. 1999). 
C.C. Sze and A. Shilatifard

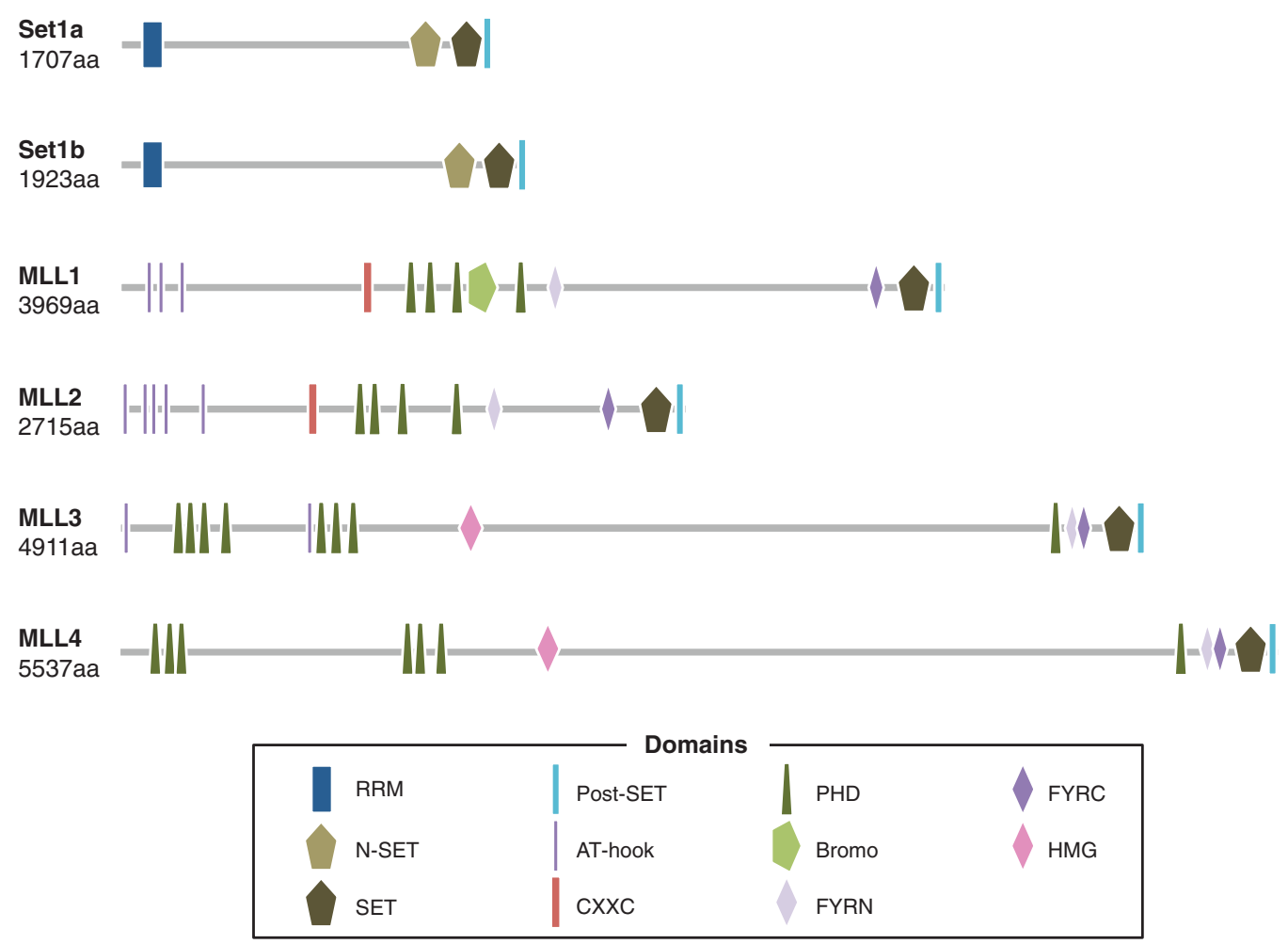

Figure 2. Known domain organization of COMPASS family members in humans. Annotation of each domain structure follows SMART (see smart.embl-heidelberg.de) (Schultz et al. 1998; Letunic et al. 2015) using protein sequences obtained from the National Center for Biotechnology Information (NCBI) as accessed on January 8 , 2016. Names for illustrated domains are specified in the box labeled "Domains." All COMPASS family members possess the highly conserved SET and post-SET domains at the carboxyl terminus. Meanwhile, the amino terminus vastly varies across the subfamilies. Mammalian Setla and Set1b have amino-terminal RNA recognition motifs (RRM) and an N-SET domain juxtaposing the SET domain. Mammalian MLL-related proteins have several plant homeodomain (PHD) fingers and other domains associated with chromatin binding (e.g., AThooks, high-mobility group [HMG] boxes, and CXXC domains). MLL1-4 methylases also have FY-rich (FYR) motifs, in which MLL1 and MLL2 have FYRN and FYRC regions distant from each other, whereas MLL3 and MLL4 have such regions adjacent to each other. The diversity in domains contributes to the binding and functional properties of the COMPASS complexes.

Trr and its mammalian homologs MLL3/ MLL4 have been accredited as key H3K4 monomethyltransferases at enhancers, primarily implementing $\mathrm{H} 3 \mathrm{~K} 4$ monomethylation at intergenic and intragenic regions (Herz et al. 2012; Hu et al. 2013a; Lee et al. 2013). In Drosophila, Trr, which contains the SET domain, corresponds to the carboxy-terminal portion of MLL3/MLL4, whereas another protein LPT (lost plant homeodomains of Trr), which contains several PHD domains and an HMG box, is homologous to the amino-terminal region of MLL3/MLL4 (Mohan et al. 2011; Herz et al. 2012). Together, Trr and LPT serve an analogous role to mammalian MLL3/MLL4. ChIP-seq studies revealed that Trr and MLL3/ MLL4 bind to enhancer regions as well as transcription start sites (Herz et al. 2012; Hu et al. 2013a). Depletion of Trr and MLL3/MLL4 resulted in a striking genome-wide reduction of $\mathrm{H} 3 \mathrm{~K} 4$ monomethylation, primarily occurring at enhancer regions (Herz et al. 2012; Hu et al. 2013a). As histone H3K27ac decreases, the $\mathrm{H} 3 \mathrm{~K} 27 \mathrm{me} 3$ levels increase at putative enhancers 
upon loss of Trr in Drosophila S2 cells or loss of MLL3/MLL4 in mouse embryonic fibroblasts (MEFs) (Herz et al. 2012; Hu et al. 2013a). Because H3K27ac and H3K27me marks are part of different enhancer chromatin signatures, these findings further implicated Trr/MLL3/ MLL4 in enhancer regulation (Herz et al. 2014). The role of Trr/MLL3/MLL4 as enhancer monomethylases regulating enhancer/promoter communication has also been confirmed by other studies of mammalian myogenesis and adipogenesis, macrophage activation, cardiac development, and B-cell lymphomagenesis (Kaikkonen et al. 2013; Lee et al. 2013; Ortega-Molina et al. 2015; Ang et al. 2016).

\section{MLL3 AND MLL4/COMPASS IN CANCER}

\section{The Mutational Landscape}

Advancement of high-throughput genome sequencing in recent years resulted in the identification of a myriad of somatic mutations of MLL3 and MLL4 across different malignancies, which include but are not limited to non-Hodgkin's lymphoma (NHL), bladder cancer, breast cancer, medulloblastoma, prostate cancer, colorectal cancer, esophageal squamous cell carcinoma, acute myeloid leukemia (AML), and cutaneous T-cell lymphoma (Ruault et al. 2002; Ashktorab et al. 2010; Gui et al. 2011; Morin et al. 2011; Parsons et al. 2011; Pasqualucci et al. 2011; Akhtar-Zaidi et al. 2012; Ellis et al. 2012; Grasso et al. 2012; Jones et al. 2012; Pugh et al. 2012; Gao et al. 2014; Lin et al. 2014; da Silva Almeida et al. 2015; Tan et al. 2015). In fact, extensive genomic analyses of these sequencing data revealed that MLL3 and MLL4/ COMPASS family mutations to be among the most frequent in human cancer (Kandoth et al. 2013; Lawrence et al. 2014). Missense and nonsense mutations of MLL3 and MLL4 are distributed along the whole length of the protein, rendering the enzyme inactive or truncated (Fig. 3) (Forbes et al. 2015). However, closer observation of the "Catalogue of Somatic Mutations in Cancer" (COSMIC) data reveals a higher density of mutations in the amino-terminal region of MLL3 containing clusters of PHD fingers, whereas mutations of MLL4, although abundant, are relatively more dispersed throughout the protein (Fig. 3) (see cancer.sanger.ac.uk/ cosmic; Forbes et al. 2015). The enrichment of mutations over the highly conserved amino-terminal region of MLL3 indicates the potential importance of these domains in cancer and justifying the need for further molecular understanding of these functional motifs (Fig. 3) (see cancer.sanger.ac.uk/cosmic; Forbes et al. 2015).

\section{TUMOR SUPPRESSOR AND ONCOGENIC ACTIVITIES}

Accumulating evidence suggests that MLL3 and MLL4/COMPASS family are tumor suppressors, such that their mutations result in abrogation of their tumor suppressing activity and promote cancer in a tissue-specific manner. Trr, the Drosophila homolog of MLL3/MLL4, was reported to negatively regulate cell proliferation, for Trr mutant clones resulted in tissue overgrowth compared with their wild-type (WT) counterparts during Drosophila eye development (Kanda et al. 2013). Another in vivo study linked MLL3/MLL4 to cancer by serving as a coactivator for $\mathrm{p} 53$ to induce expression of p53 target genes involved in DNA damage response (Lee et al. 2009). The same team reported that mice with deleted SET domain of MLL3 developed ureter epithelial tumors, which was exacerbated in a $p 53^{+/-}$background, hinting that the enzymatic activity may be required in inhibiting tumorigenesis (Lee et al. 2009). Newly published evidence has implicated MLL4 in genomic instability (Kantidakis et al. 2016), one of the essential enabling characteristics underlying oncogenesis as described by Hanahan and Weinberg in 2011 (Hanahan and Weinberg 2011). By targeting both alleles of MLL4 in immortalized MEFs and using human MLL4-KO HCT116 cells, Kantidakis et al. (2016) reported that such MLL4 deficiency results in significant perturbation of genomic integrity, including increase sister chromatid exchange and/or chromosomal abnormalities, and induced transcription stress, that is, slow elongation. A recent study has provided a dif- 
C.C. Sze and A. Shilatifard
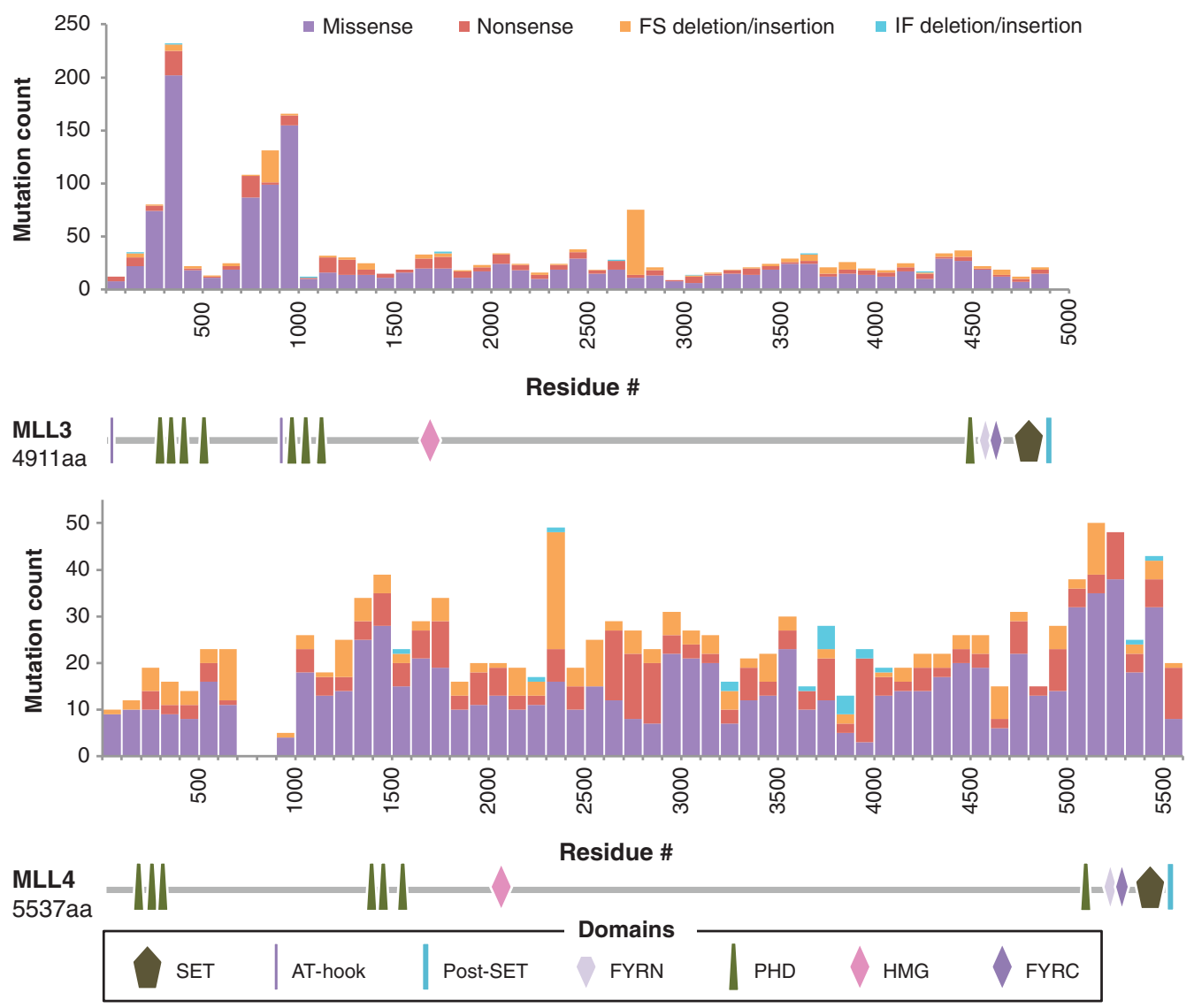

Figure 3. Mutations of MLL3/MLL4 identified in cancer patient samples. Missense and nonsense mutations, frameshift (FS) deletions and insertions, and in-frame (IF) deletions and insertions of MLL3 and MLL4 were obtained from the Catalogue of Somatic Mutations in Cancer (COSMIC) database (see cancer.sanger.ac.uk/ cosmic; Forbes et al. 2015). Note that COSMIC reports sites of MLL4 mutations aligned to an alternatively spliced transcript encoding a shorter MLL4 protein (5268 amino acids). In the present schematic, the positions of these mutations were adjusted to match the 5537-amino-acid protein most commonly reported in the literature. To generate the bar plot, binning of 100 residues across each protein was performed, and mutations were categorized by mutation type. The plot shows the number of unique mutated patient samples for a specific mutation ("mutation count"), as documented by COSMIC. Domain schematic of MLL3 and MLL4 to serve as reference, and names for illustrated domains are specified in the box labeled "Domains."

ferent angle of MLL4 involvement in cancer: gain-of-function p53, an oncogenic p53 mutant resulting from a missense mutation in its DNAbinding domain, interacts with and up-regulates a set of chromatin regulators that include MLL1 and MLL4, resulting in altered genomewide methylation patterns, whereas the WT p53 did not bind these genes or affect their expression (Zhu et al. 2015). The same study showed that knockdown of MLL1 or MLL4 in gain-of- function $p 53$ breast cancer cells severely reduced cell growth, phenocopying knockdown of gainof-function p53 (Zhu et al. 2015). Together, these studies clearly indicate that role of MLL4 in cancer is context dependent.

Several studies point to a role for MLL3 and MLL4/COMPASS as tumor suppressors against a wide variety of neoplasms. MLL3 was identified as a novel haploinsufficient tumor suppressor in 7q-deficient myelodysplastic syndrome 
(MDS) and AML (Chen et al. 2014). Chromosomal deletions of $7 q$ occur frequently in MDS and AML and correlate with poor patient prognosis. It turns out that $7 \mathrm{q}$ deletion results in MLL3 loss, which frequently co-occurs with neurofibromin-1 (NF1) suppression and p53 inactivation (Chen et al. 2014). The investigators found that transplantation of $p 53$-deficient hematopoietic stem and progenitor cells (HSPCs), with simultaneous knockdown of MLL3 and NF1, resulted in overt myeloid leukemia in mice. In contrast, suppression of MLL3 and NF1 in WT HSPCs did not induce leukemogenesis, and MLL3-only knockdown in p53-deficient HSPCs did not accelerate p53 $3^{-/-}$-induced thymic lymphoma (Chen et al. 2014). To support these findings, the team executed the CRISPR-Cas9 strategy to disrupt MLL3 in p53-deficient HSPCs with NF1knockdown, which similarly led to AML pathogenesis. Sequencing of resulting AML clones confirmed that the clones contained heterozygous WT MLL3, a compelling finding signifying that MLL3 haploinsufficiency in coordination with NF1 and p53 suppression promotes AML (Chen et al. 2014).

MLL3 was also shown to exert tumor suppressive function in an aggressive form of AML with FLT3-ITD mutation (Garg et al. 2015). In this form of AML, internal tandem duplication (ITD) of Fms-like tyrosine kinase 3 (FLT3) renders the kinase constitutively active, and FLT3ITD AML patients eventually face tumor relapse or drug resistance. In this study, whole exome sequencing followed by targeted deep sequencing in FLT3-ITD AML patients led to the identification of missense and nonsense mutations of MLL3 (Garg et al. 2015). Prognostic analyses revealed that patients with MLL3 mutations had worse overall survival and relapse-free survival than those without MLL3 mutations (Garg et al. 2015). RNAi-knockdown of MLL3 in FLT3-ITD AML cell lines promoted cell proliferation and clonogenic growth and induced tumorigenicity in xenograft models (Garg et al. 2015). The investigators' additional analyses of The Cancer Genome Atlas (TCGA) data further supported that MLL3 is inactivated in AML (including FLT3-ITD AML) (Garg et al. 2015).
Two independent studies delved into understanding the mechanism by which mutated MLL4 contributes to diffuse large B-cell lymphoma (DLBCL) and follicular lymphoma (FL), the two most common types of NHL derived from germinal center B cells. In one study, MLL4 knockdown in hematopoietic progenitor cells (HPCs) with overexpression of the $\mathrm{Bcl} 2$ oncogene markedly accelerated lymphomagenesis in mice, which also developed splenomegaly (Ortega-Molina et al. 2015). Closer examination revealed a delayed germinal center involution and greater expansion of undifferentiated B cells, which were also unable to undergo proper class switch recombination and had reduced antibody production (Ortega-Molina et al. 2015). Gene expression analysis identified similar changes in transcription in mouse and human FL tumors, with the set of genes involved in early antigen immune signaling and B-cell differentiation being perturbed on MLL4 deficiency (Ortega-Molina et al. 2015). ChIPseq analysis showed significant loss of H3K4 mono- and dimethylation at putative enhancers of lymphoid tumor suppressor genes that regulate $\mathrm{B}$-cell signaling and that were downregulated in MLL4-deficient cells (Ortega-Molina et al. 2015). In a separate study, Pasqualucci and colleagues established conditional knockout mouse models mimicking two key stages of B-cell development, and found that conditional deletion of MLL4 early in B-cell development before germinal center initiation resulted in germinal center expansion with high B-cell proliferation, whereas MLL4 deficiency after germinal center initiation did not perturb B-cell development (Zhang et al. 2015). Loss of MLL4 before germinal center induction resulted in significant transcriptional changes, specifically up-regulation of antiapoptotic genes and down-regulation of genes promoting B-cell differentiation, indicating that MLL4 depletion confers a survival and proliferative advantage for undifferentiated $\mathrm{B}$ cells (Zhang et al. 2015). Taken together, the two parallel studies illustrate specific mechanisms by which MLL4 mutation subverts B-cell identity to that of driving lymphoid malignancies. 


\section{MODELS FOR MALFUNCTION OF MLL3/ MLL4/COMPASS FAMILY ON ENHANCERS IN CANCER}

Because mutations of the enhancer-associated H3K4 monomethylases MLL3/MLL4 occur in cancer, combined with recent findings illustrating their tumor suppressor roles, disruption of MLL3/MLL4-regulated enhancer activity could contribute to cancer by a variety of mechanisms (Herz et al. 2014). A nonsense or missense mutation could render MLL3/MLL4 truncated or catalytically inactive, resulting in loss of function of the monomethylase. A truncating mutation could promote destabilization of this COMPASS family or decrease the affinity of MLL3/MLL4 with transcription factors and other cofactors, attenuating their binding at specific enhancers of key tumor suppressor genes that consequently diminishes activation of gene expression (Herz et al. 2014). In addition, these loss-of-function mutations of MLL3/MLL4 could have broader effects by reducing enhancer activity across the genome. In an alternative scenario, MLL3/MLL4 may drive tumorigenesis via a potential gain-of-function role, in which such gain-of-function mutations may stabilize the MLL3/MLL4 COMPASS family, heighten the catalytic activity, or strengthen the interaction of MLL3/MLL4 with other transcription factors, and subsequently increase their binding to enhancers at specific loci or across the genome (Herz et al. 2014). This gain-of-function role has been implicated in the recent study that discovered the up-regulation of the MLL3/MLL4 chromatin regulators in the context of oncogenic gain-of-function p53 and their potential contribution to gainof-function p53-promoting cancer (Zhu et al. 2015). Although Zhu et al. (2015) did not report specific gain-of-function mutations in MLL4, we cannot exclude the possibility of MLL3/ MLL4 gain-of-function mutations existing in breast cancer and other tumor types. With the two opposing model scenarios in mind, we still have key outstanding questions that should help further advance our understanding of the role of MLL3/MLL4 in cancer pathogenesis. For instance, how exactly do MLL3/MLL4 mutations aberrantly elicit gene expression to ultimately subvert cellular identity and promote tumorigenesis, and how do these underlying mechanisms differ across tumor types? Could mutations at particular domains have distinct molecular ramifications? Mutations within the PHD finger might disrupt recognition of the appropriate marks necessary for recruitment to chromatin, whereas mutations in the SET domain could alter the enzyme's catalytic activity. To date, specific downstream molecular effects of different regulatory domain interactions are still unclear (Henikoff and Shilatifard 2011). Furthermore, finding the key players involved in mobilizing MLL3/MLL4 to enhancer regions, and determining if these factors are themselves mutated to dysregulate MLL3/MLL4 recruitment and consequently their function will be important to understand the full spectrum of MLL3/4 contributions to cancer and help provide key therapeutic strategies for targeting MLL3/MLL4-mediated cancers.

\section{UTX SUBUNIT OF MLL3/MLL4/COMPASS FAMILY AND CANCER}

As shown in Figure 1, MLL3 and MLL4 each exist in a multimeric composition within COMPASS with additional components exclusive to the two methyltransferases. Interestingly, one such subunit, ubiquitously transcribed tetratricopeptide repeat on chromosome $\underline{X}$ (UTX), has also been documented to be frequently mutated in cancer (Kandoth et al. 2013; Lawrence et al. 2014). UTX (also known as $\mathrm{KDM} 6 \mathrm{~A}$ ) is a histone lysine demethylase that specifically removes methyl groups from di- and trimethylated H3K27, the latter a histone mark typically associated with gene repression and chromatin compaction (Agger et al. 2007; Margueron et al. 2008; Smith et al. 2008; Herz et al. 2010). Methylation of H3K27 is deposited by Polycomb repressive complex 2 (PRC2) at both enhancers and promoters and subsequently recognized by PRC1 to silence transcription (Margueron and Reinberg 2011; Piunti and Shilatifard 2016). Thus, the WT enzymatic activity of UTX could serve to antagonize Polycomb-mediated repression. In Dro- 
sophila, ChIP-seq studies found that UTX colocalized with Trr at transcriptional start sites and putative enhancers, with Trr-RNAi-induced loss of UTX resulting in increased trimethylated H3K27 and decreased H3K27ac at enhancer regions (Herz et al. 2012). Therefore, the presence of UTX in the Trr/MLL3/MLL4 branch of the COMPASS family suggests that UTX may act as an enhancer-specific $\mathrm{H} 3 \mathrm{~K} 27$ demethylase to facilitate the transition from inactive to active enhancers (Herz et al. 2012).

Somatic mutations of UTX are found in various tumor types, including bladder cancer, pancreatic cancer, renal carcinoma, and T-cell acute lymphoblastic leukemia (T-ALL) (van Haaften et al. 2009; Dalgliesh et al. 2010; Gui et al. 2011; Mar et al. 2012; Ntziachristos et al. 2014; Van der Meulen et al. 2015; Waddell et al. 2015). Thus far, the highest frequency of mutations documented to date is in bladder carcinoma (as high as $40 \%$ ), in which UTX alterations have been found to occur more frequently in early stages and grades of bladder cancer (see cancer.sanger.ac.uk/cosmic; Gui et al. 2011; Gao et al. 2013; Kandoth et al. 2013; Kim et al. 2015). Although mutations are distributed throughout the UTX protein, there appears to be a higher density of mutations localized around the Jumonji C (JmjC) demethylase domain (Fig. 4) (see cancer.sanger.ac.uk/cosmic). Accordingly, loss of UTX expression has been correlated with poor patient prognosis (Wang et al. 2010). UTX is expressed from the X chromosome and escapes $\mathrm{X}$ inactivation in females, while males have a paralog on the Y chromosome named UTY (Greenfield et al. 1998). In several female cancer cell lines, UTX mutations have been reported to be homozygous, while in males there is a tendency for mutation of the single UTX gene to be associated with genomic loss of UTY (van Haaften et al. 2009). This suggests that there is an allelic function of UTY for UTX, although studies have shown the lack of H3K27 demethylase activity of purified UTY (Hong et al. 2007; Lan et al. 2007). Nonetheless, the tendency for biallelic UTX inactivation in females and the two-hit UTX-UTY loss in males contributing to oncogenesis further indicates the potential tumor suppressor function of UTX (van Haaften et al. 2009).

The role of UTX as a cell growth regulator and tumor suppressor is being increasingly ex-

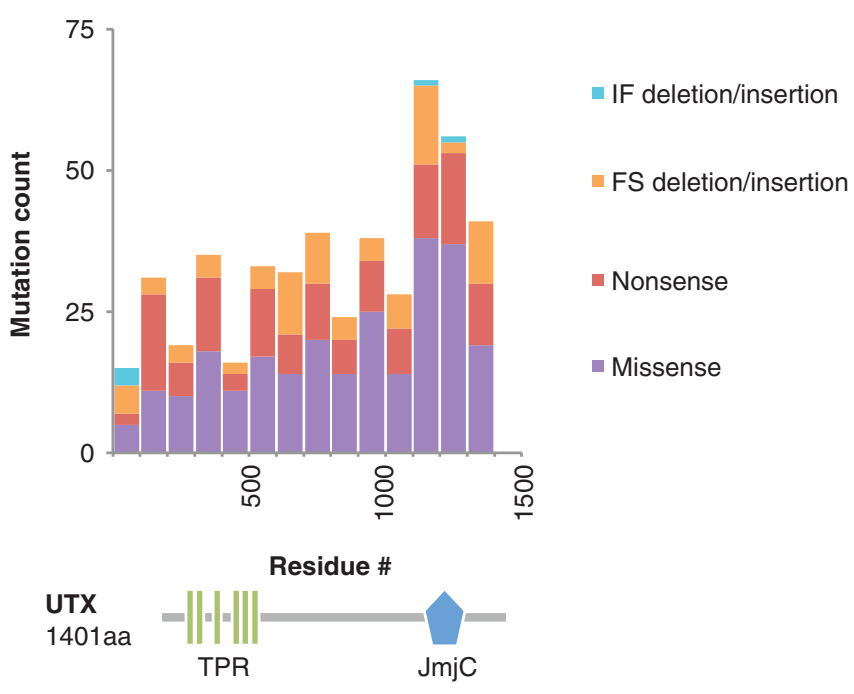

Figure 4. Identified mutations of UTX in cancer. Mutations were also obtained from the COSMIC database (refer to Fig. 3 legend for additional details). The plot was generated similarly as in Figure 3, with domain schematic of UTX to serve as reference. Domain annotation of UTX follows SMART using protein sequence obtained from NCBI (accessed January 8, 2016). TPR, Tetratricopeptide repeat; JmjC, Jumonji C. 
plored. We and others showed in Drosophila that mutant clones of UTX show increased H3K27 trimethylation and are associated with a major growth advantage compared with the surrounding cells (Herz et al. 2010; Kanda et al. 2013). UTX was also found to control cell cycle and growth by antagonizing Notch signaling and modulating the activity of the known tumor suppressor retinoblastoma $(\mathrm{Rb})$ protein, such that UTX mutations led to Notch overactivation and consequently to tumor-like growth in an Rb-dependent manner (Herz et al. 2010). A separate study using human fibroblasts found that UTX demethylated H3K27 trimethylation at key $\mathrm{Rb}$-binding proteins, thereby maintaining their expression to facilitate cell-cycle arrest (Wang et al. 2010). To test the functional consequence of missense mutations identified in adenoid cystic carcinomas, WT or mutant UTX was overexpressed in HEK293T cells. Overexpression of mutant UTX led to increased cell growth and increased $\mathrm{H} 3 \mathrm{~K} 27$ trimethylation (Ho et al. 2013). Together, these studies support a tumor suppressor role for UTX from flies to mammals underlying the frequent mutation of UTX in cancer. Importantly, in Drosophila, loss of UTX also resulted in a significant reduction of global $\mathrm{H} 3 \mathrm{~K} 4$ monomethylation indicating that UTX could function at enhancer regions to mediate its tumor suppressor activity (Herz et al. 2010). This is further supported by the co-occurrence in bladder cancer of mutations of UTX and EP300 (p300) or CREBBP (CBP), histone acetyltransferases responsible for $\mathrm{H} 3 \mathrm{~K} 27 \mathrm{ac}$ at active enhancers (Pasini et al. 2010; Gui et al. 2011).

Two independent teams recently showed that UTX is a tumor suppressor in T-ALL using a NOTCH1-induced T-ALL in vivo model. In one study, knockout UTX mice succumbed to the disease more quickly than those with WT UTX (Ntziachristos et al. 2014). The second study found that UTX knockdown significantly accelerated leukemic onset (Van der Meulen et al. 2015). T-ALL is an aggressive form of leukemia that is diagnosed more often in males than females, which may at least be partly attributed to the fact that UTX is expressed from the $\mathrm{X}$ chromosome. Indeed, sequencing of pa- tient samples identified inactivating/truncating UTX mutations primarily in samples of male origin (Ntziachristos et al. 2014; Van der Meulen et al. 2015). Furthermore, gene expression profiling of UTX-deficient T-ALL mouse tumors showed that these tumors have downregulated expression of key tumor suppressor genes, strongly pinpointing UTX as a critical tumor suppressor in T-ALL (Ntziachristos et al. 2014; Van der Meulen et al. 2015). In fact, UTX overexpression via a doxycycline-inducible lentiviral system in a T-ALL cell line significantly promoted apoptosis (Ntziachristos et al. 2014).

The recent findings discussed above provide an initial understanding of the tumor suppressive role of UTX in human cancers; however, emerging evidence indicates that this role is cancer subtype- and tissue-specific. In a specific subtype of T-ALL driven by oncogenic transcription factor TAL1, UTX was identified as a coactivator of TAL1 that gets recruited to TAL1targets to remove $\mathrm{H} 3 \mathrm{~K} 27$ trimethylation, thereby facilitating the expression of proproliferative and antiapoptotic genes (Benyoucef et al. 2016). Through depletion and overexpression experiments, the investigators indicated a selective oncogenic role of UTX in TAL1-positive T-ALL, but a tumor suppressive role in TAL1-negative T-ALL (Benyoucef et al. 2016). This functional distinction of UTX between molecular subtypes of T-ALL was further supported in patientderived xenografts, in which treatment with H3K27 demethylase inhibitor GSK-J4 dramatically reduced percentage of human leukemic blasts and splenomegaly in TAL1-positive models, with no effect on TAL1-negative models (Benyoucef et al. 2016). In a separate study using breast cancer cells, aberrant UTX overexpression contributed to cell proliferation, anchorage-independent growth, and invasiveness, and UTX and MLL4 were intriguingly found to coregulate a set of genes linked with proliferation and invasiveness (Kim et al. 2014). Through knockdown and quantitative ChIP experiments, the investigators connected UTX demethylation of $\mathrm{H} 3 \mathrm{~K} 27$ trimethylation with increased MLL4-dependent H3K4 trimethylation at the promoters of cotarget genes, suggesting 
that UTX and MLL4 cooccupy the same loci to coordinately activate expression of oncogenes in breast cancer (Kim et al. 2014). Given findings from other studies, it is also possible that UTX and MLL4 may cooperatively control tumorigenic transcriptional programs in breast cancer by regulating enhancers of oncogenes, which in turn activates their associated promoters. Nevertheless, the ability of MLL3/MLL4 and UTX with the COMPASS family to act as tumor suppressors or oncogenes depends on the molecular and cellular circumstances, and reveals a critical need to define the precise mechanism through which MLL3/MLL4 and UTX act in each specific context and how their abnormal changes impact individual tumors.

\section{CONCLUDING REMARKS}

MLL3/MLL4 and UTX of the COMPASS family play a key tumor suppressor role across the breadth of cancers, although there are cases in which these chromatin modifiers may have an alternative tumorigenic role that is dependent on the cellular context. At this time, the mechanistic relationship between MLL3/MLL4 and UTX and their regulation of enhancer activity, whether global or local, in development and disease is still unclear. Given the complexity underlying the biological role of these chromatin proteins in cancer pathogenesis, additional research in various developmental processes is necessary to understand the fundamental mechanism and precise functional impact of MLL3/MLL4 and UTX alterations. With the rapid development and advancement of nextgeneration sequencing methods, determining novel mutations, and distinguishing those that are cooccurring and mutually exclusive in cancer will also be important to elucidate the signaling pathways likely deregulated by alterations of these chromatin-modifying enzymes. These technologies will also enable genomewide identification of MLL3/MLL4/UTXdependent enhancers in normal and cancerous conditions, with the potential to characterize enhancers of tumor suppressors and/or oncogenes. Use of groundbreaking tools such as CRISPR-Cas9 will permit further investigation of these MLL3/MLL4/UTX-dependent enhancers, giving us the precision to genetically edit endogenous loci to examine enhancer function. Together, these studies will ultimately provide critical insights to facilitate the identification of therapeutic opportunities for cancer.

\section{ACKNOWLEDGMENTS}

We are grateful to Dr. Edwin Smith for critical reading and comments on this manuscript. C.S.S. is supported, in part, by National Institutes of Health/National Cancer Institute (NIH/NCI) training Grant T32CA09560. Studies in A.S.'s laboratory regarding the role of the COMPASS family in development and cancer are supported by NCI Grant R35CA197569.

\section{REFERENCES}

Agger K, Cloos PA, Christensen J, Pasini D, Rose S, Rappsilber J, Issaeva I, Canaani E, Salcini AE, Helin K. 2007. UTX and JMJD3 are histone H3K27 demethylases involved in HOX gene regulation and development. Nature 449: $731-734$.

Akhtar-Zaidi B, Cowper-Sal-lari R, Corradin O, Saiakhova A, Bartels CF, Balasubramanian D, Myeroff L, Lutterbaugh J, Jarrar A, Kalady MF, et al. 2012. Epigenomic enhancer profiling defines a signature of colon cancer. Science 336: 736-739.

Allis CD, Berger SL, Cote J, Dent S, Jenuwien T, Kouzarides T, Pillus L, Reinberg D, Shi Y, Shiekhattar R, et al. 2007. New nomenclature for chromatin-modifying enzymes. Cell 131: 633-636.

Ang SY, Uebersohn A, Spencer CI, Huang Y, Lee JE, Ge K, Bruneau BG. 2016. KMT2D regulates specific programs in heart development via histone $\mathrm{H} 3$ lysine 4 di-methylation. Development 143: 810-821.

Aran D, Sabato S, Hellman A. 2013. DNA methylation of distal regulatory sites characterizes dysregulation of cancer genes. Genome Biol 14: R21.

Ardehali MB, Mei A, Zobeck KL, Caron M, Lis JT, Kusch T. 2011. Drosophila Set1 is the major histone H3 lysine 4 trimethyltransferase with role in transcription. EMBO J 30: $2817-2828$.

Ashktorab H, Schaffer AA, Daremipouran M, Smoot DT, Lee E, Brim H. 2010. Distinct genetic alterations in colorectal cancer. PLoS ONE 5: e8879.

Banerji J, Rusconi S, Schaffner W. 1981. Expression of a $\beta$ globin gene is enhanced by remote SV40 DNA sequences. Cell 27: 299-308.

Benyoucef A, Palii CG, Wang C, Porter CJ, Chu A, Dai F, Tremblay V, Rakopoulos P, Singh K, Huang S, et al. 2016. UTX inhibition as selective epigenetic therapy against TAL1-driven T-cell acute lymphoblastic leukemia. Genes Dev 30: $508-521$. 
C.C. Sze and A. Shilatifard

Blackwood EM, Kadonaga JT. 1998. Going the distance: A current view of enhancer action. Science 281: 60-63.

Breen TR, Harte PJ. 1991. Molecular characterization of the trithorax gene, a positive regulator of homeotic gene expression in Drosophila. Mech Dev 35: 113 127.

Bulger M, Groudine M. 2011. Functional and mechanistic diversity of distal transcription enhancers. Cell 144: 327 339.

Chen C, Liu Y, Rappaport AR, Kitzing T, Schultz N, Zhao Z Shroff AS, Dickins RA, Vakoc CR, Bradner JE, et al. 2014. MLL3 is a haploinsufficient 7q tumor suppressor in acute myeloid leukemia. Cancer cell 25: 652-665.

Creyghton MP, Cheng AW, Welstead GG, Kooistra T, Carey BW, Steine EJ, Hanna J, Lodato MA, Frampton GM, Sharp PA, et al. 2010. Histone H3K27ac separates active from poised enhancers and predicts developmental state. Proc Natl Acad Sci 107: 21931-21936.

da Silva Almeida AC, Abate F, Khiabanian H, Martinez-Escala E, Guitart J, Tensen CP, Vermeer MH, Rabadan R, Ferrando A, Palomero T. 2015. The mutational landscape of cutaneous T cell lymphoma and Sézary syndrome. Nat Genet 47: 1465-1470.

Dalgliesh GL, Furge K, Greenman C, Chen L, Bignell G, Butler A, Davies H, Edkins S, Hardy C, Latimer C, et al. 2010. Systematic sequencing of renal carcinoma reveals inactivation of histone modifying genes. Nature 463: 360-363.

Djabali M, Selleri L, Parry P, Bower M, Young BD, Evans GA. 1992. A trithorax-like gene is interrupted by chromosome $11 \mathrm{q} 23$ translocations in acute leukaemias. Nat $\mathrm{Ge}$ net 2: 113-118.

Dorsett D. 1999. Distant liaisons: Long-range enhancerpromoter interactions in Drosophila. Curr Opin Genet Dev 9: 505-514.

Dorsett D, Merkenschlager M. 2013. Cohesin at active genes: A unifying theme for cohesin and gene expression from model organisms to humans. Curr Opin Cell Biol 25: 327-333.

Eissenberg JC, Shilatifard A. 2010. Histone H3 lysine 4 (H3K4) methylation in development and differentiation. Dev Biol 339: 240-249.

Ellis MJ, Ding L, Shen D, Luo J, Suman VJ, Wallis JW, Van Tine BA, Hoog J, Goiffon RJ, Goldstein TC, et al. 2012. Whole-genome analysis informs breast cancer response to aromatase inhibition. Nature 486: 353-360.

Forbes SA, Beare D, Gunasekaran P, Leung K, Bindal N, Boutselakis H, Ding M, Bamford S, Cole C, Ward S, et al. 2015. COSMIC: Exploring the world's knowledge of somatic mutations in human cancer. Nucleic Acids Res 43: D805-811.

Gao J, Aksoy BA, Dogrusoz U, Dresdner G, Gross B, Sumer SO, Sun Y, Jacobsen A, Sinha R, Larsson E, et al. 2013. Integrative analysis of complex cancer genomics and clinical profiles using the cBioPortal. Sci Signal 6: pll.

Gao YB, Chen ZL, Li JG, Hu XD, Shi XJ, Sun ZM, Zhang F, Zhao ZR, Li ZT, Liu ZY, et al. 2014. Genetic landscape of esophageal squamous cell carcinoma. Nat Genet 46: 1097-1102.
Garg M, Nagata Y, Kanojia D, Mayakonda A, Yoshida K, Haridas Keloth S, Zang ZJ, Okuno Y, Shiraishi Y, Chiba $\mathrm{K}$, et al. 2015. Profiling of somatic mutations in acute myeloid leukemia with FLT3-ITD at diagnosis and relapse. Blood 126: 2491-2501.

Grasso CS, Wu YM, Robinson DR, Cao X, Dhanasekaran SM, Khan AP, Quist MJ, Jing X, Lonigro RJ, Brenner JC, et al. 2012. The mutational landscape of lethal castrationresistant prostate cancer. Nature 487: 239-243.

Greenfield A, Carrel L, Pennisi D, Philippe C, Quaderi N, Siggers P, Steiner K, Tam PP, Monaco AP, Willard HF, et al. 1998. The UTX gene escapes X inactivation in mice and humans. Hum Mol Genet 7: 737-742.

Gu Y, Nakamura T, Alder H, Prasad R, Canaani O, Cimino G, Croce CM, Canaani E. 1992. The t $(4 ; 11)$ chromosome translocation of human acute leukemias fuses the $A L L-1$ gene, related to Drosophila trithorax, to the AF-4 gene. Cell 71: 701-708.

Gui Y, Guo G, Huang Y, Hu X, Tang A, Gao S, Wu R, Chen C, Li X, Zhou L, et al. 2011. Frequent mutations of chromatin remodeling genes in transitional cell carcinoma of the bladder. Nat Genet 43: 875-878.

Hallson G, Hollebakken RE, Li T, Syrzycka M, Kim I, Cotsworth S, Fitzpatrick KA, Sinclair DA, Honda BM. 2012. dSet1 is the main H3K4 di- and tri-methyltransferase throughout Drosophila development. Genetics 190: 91100.

Hanahan D, Weinberg RA. 2011. Hallmarks of cancer: The next generation. Cell 144: 646-674.

Heintzman ND, Stuart RK, Hon G, Fu Y, Ching CW, Hawkins RD, Barrera LO, Van Calcar S, Qu C, Ching KA, et al. 2007. Distinct and predictive chromatin signatures of transcriptional promoters and enhancers in the human genome. Nat Genet 39: 311-318.

Heintzman ND, Hon GC, Hawkins RD, Kheradpour P, Stark A, Harp LF, Ye Z, Lee LK, Stuart RK, Ching CW, et al. 2009. Histone modifications at human enhancers reflect global cell-type-specific gene expression. Nature 459: $108-112$.

Henikoff S, Shilatifard A. 2011. Histone modification: Cause or cog? Trends Genet 27: 389-396.

Herz HM, Madden LD, Chen Z, Bolduc C, Buff E, Gupta R, Davuluri R, Shilatifard A, Hariharan IK, Bergmann A. 2010. The H3K27me3 demethylase dUTX is a suppressor of Notch- and Rb-dependent tumors in Drosophila. Mol Cell Biol 30: 2485-2497.

Herz HM, Mohan M, Garruss AS, Liang K, Takahashi YH, Mickey K, Voets O, Verrijzer CP, Shilatifard A. 2012. Enhancer-associated H3K4 monomethylation by trithoraxrelated, the Drosophila homolog of mammalian Mll3 Mll4. Genes Dev 26: 2604-2620.

Herz HM, Garruss A, Shilatifard A. 2013. SET for life: Biochemical activities and biological functions of SET domain-containing proteins. Trends Biochem Sci 38: 621639.

Herz HM, Hu D, Shilatifard A. 2014. Enhancer malfunction in cancer. Mol Cell 53: 859-866.

Ho AS, Kannan K, Roy DM, Morris LG, Ganly I, Katabi N, Ramaswami D, Walsh LA, Eng S, Huse JT, et al. 2013. The mutational landscape of adenoid cystic carcinoma. Nat Genet 45: 791-798. 
Hong S, Cho YW, Yu LR, Yu H, Veenstra TD, Ge K. 2007. Identification of JmjC domain-containing UTX and JMJD3 as histone H3 lysine 27 demethylases. Proc Natl Acad Sci 104: 18439-18444.

Hu D, Gao X, Morgan MA, Herz HM, Smith ER, Shilatifard A. 2013a. The MLL3/MLL4 branches of the COMPASS family function as major histone $\mathrm{H} 3 \mathrm{~K} 4$ monomethylases at enhancers. Mol Cell Biol 33: 4745-4754.

Hu D, Garruss AS, Gao X, Morgan MA, Cook M, Smith ER, Shilatifard A. 2013b. The Mll2 branch of the COMPASS family regulates bivalent promoters in mouse embryonic stem cells. Nat Struct Mol Biol 20: 488: 100-105.

Jones DT, Jager N, Kool M, Zichner T, Hutter B, Sultan M, Cho YJ, Pugh TJ, Hovestadt V, Stutz AM, et al. 2012. Dissecting the genomic complexity underlying medulloblastoma. Nature 488: 100-105.

Kagey MH, Newman JJ, Bilodeau S, Zhan Y, Orlando DA, van Berkum NL, Ebmeier CC, Goossens J, Rahl PB, Levine SS, et al. 2010. Mediator and cohesin connect gene expression and chromatin architecture. Nature 467: 430 435.

Kaikkonen MU, Spann NJ, Heinz S, Romanoski CE, Allison KA, Stender JD, Chun HB, Tough DF, Prinjha RK, Benner C, et al. 2013. Remodeling of the enhancer landscape during macrophage activation is coupled to enhancer transcription. Mol Cell 51: 310-325.

Kanda H, Nguyen A, Chen L, Okano H, Hariharan IK. 2013. The Drosophila ortholog of MLL3 and MLL4, trithorax related, functions as a negative regulator of tissue growth. Mol Cell Biol 33: 1702-1710.

Kandoth C, McLellan MD, Vandin F, Ye K, Niu B, Lu C, Xie M, Zhang Q, McMichael JF, Wyczalkowski MA, et al. 2013. Mutational landscape and significance across 12 major cancer types. Nature 502: 333-339.

Kantidakis T, Saponaro M, Mitter R, Horswell S, Kranz A, Boeing S, Aygun O, Kelly GP, Matthews N, Stewart A, et al. 2016. Mutation of cancer driver MLL2 results in transcription stress and genome instability. Genes Dev 30: $408-420$.

Kim JH, Sharma A, Dhar SS, Lee SH, Gu B, Chan CH, Lin HK, Lee MG. 2014. UTX and MLL4 coordinately regulate transcriptional programs for cell proliferation and invasiveness in breast cancer cells. Cancer Res 74: 1705-1717.

Kim PH, Cha EK, Sfakianos JP, Iyer G, Zabor EC, Scott SN, Ostrovnaya I, Ramirez R, Sun A, Shah R, et al. 2015. Genomic predictors of survival in patients with highgrade urothelial carcinoma of the bladder. Eur Urol 67: 198-201.

Klymenko T, Muller J. 2004. The histone methyltransferases Trithorax and Ash1 prevent transcriptional silencing by Polycomb group proteins. EMBO Rep 5: 373-377.

Krogan NJ, Dover J, Khorrami S, Greenblatt JF, Schneider J, Johnston M, Shilatifard A. 2002. COMPASS, a histone H3 (Lysine 4) methyltransferase required for telomeric silencing of gene expression. J Biol Chem 277: $10753-$ 10755.

Kurdistani SK. 2012. Enhancer dysfunction: How the main regulators of gene expression contribute to cancer. Genome Biol 13: 156

Lan F, Bayliss PE, Rinn JL, Whetstine JR, Wang JK, Chen S, Iwase S, Alpatov R, Issaeva I, Canaani E, et al. 2007. A histone $\mathrm{H} 3$ lysine 27 demethylase regulates animal posterior development. Nature 449: 689-694.

Lawrence MS, Stojanov P, Mermel CH, Robinson JT, Garraway LA, Golub TR, Meyerson M, Gabriel SB, Lander ES, Getz G. 2014. Discovery and saturation analysis of cancer genes across 21 tumour types. Nature 505: 495501.

Lee J, Kim DH, Lee S, Yang QH, Lee DK, Lee SK, Roeder RG, Lee JW. 2009. A tumor suppressive coactivator complex of p53 containing ASC-2 and histone H3-lysine-4 methyltransferase MLL3 or its paralogue MLL4. Proc Natl Acad Sci 106: 8513-8518.

Lee JE, Wang C, Xu S, Cho YW, Wang L, Feng X, Baldridge A, Sartorelli V, Zhuang L, Peng W, et al. 2013. H3K4 monoand di-methyltransferase MLL4 is required for enhancer activation during cell differentiation. eLife 2: e01503.

Letunic I, Doerks T, Bork P. 2015. SMART: Recent updates, new developments and status in 2015. Nucleic Acids Res 43: D257-260.

Levine M, Cattoglio C, Tjian R. 2014. Looping back to leap forward: Transcription enters a new era. Cell 157: 13-25.

Lin DC, Hao JJ, Nagata Y, Xu L, Shang L, Meng X, Sato Y, Okuno Y, Varela AM, Ding LW, et al. 2014. Genomic and molecular characterization of esophageal squamous cell carcinoma. Nat Genet 46: 467-473.

Loven J, Hoke HA, Lin CY, Lau A, Orlando DA, Vakoc CR, Bradner JE, Lee TI, Young RA. 2013. Selective inhibition of tumor oncogenes by disruption of super-enhancers. Cell 153: 320-334.

Mahmoudi T, Verrijzer CP. 2001. Chromatin silencing and activation by Polycomb and trithorax group proteins. Oncogene 20: 3055-3066.

Maniatis T, Goodbourn S, Fischer JA. 1987. Regulation of inducible and tissue-specific gene expression. Science 236: 1237-1245.

Mar BG, Bullinger L, Basu E, Schlis K, Silverman LB, Dohner K, Armstrong SA. 2012. Sequencing histone-modifying enzymes identifies UTX mutations in acute lymphoblastic leukemia. Leukemia 26: 1881-1883.

Margueron R, Reinberg D. 2011. The Polycomb complex PRC2 and its mark in life. Nature 469: 343-349.

Margueron R, Li G, Sarma K, Blais A, Zavadil J, Woodcock CL, Dynlacht BD, Reinberg D. 2008. Ezh1 and Ezh2 maintain repressive chromatin through different mechanisms. Mol Cell 32: 503-518.

Miller T, Krogan NJ, Dover J, Erdjument-Bromage H, Tempst P, Johnston M, Greenblatt JF, Shilatifard A. 2001. COMPASS: A complex of proteins associated with a trithorax-related SET domain protein. Proc Natl Acad Sci 98: 12902-12907.

Mohan M, Herz HM, Smith ER, Zhang Y, Jackson J, Washburn MP, Florens L, Eissenberg JC, Shilatifard A. 2011. The COMPASS family of H3K4 methylases in Drosophila. Mol Cell Biol 31: 4310-4318.

Morgan MA, Shilatifard A. 2015. Chromatin signatures of cancer. Genes Dev 29: 238-249.

Morin RD, Mendez-Lago M, Mungall AJ, Goya R, Mungall KL, Corbett RD, Johnson NA, Severson TM, Chiu R, Field M, et al. 2011. Frequent mutation of histone-modifying genes in non-Hodgkin lymphoma. Nature 476: $298-303$. 
C.C. Sze and A. Shilatifard

Ntziachristos P, Tsirigos A, Welstead GG, Trimarchi T, Bakogianni S, Xu L, Loizou E, Holmfeldt L, Strikoudis A, King B, et al. 2014. Contrasting roles of histone 3 lysine 27 demethylases in acute lymphoblastic leukaemia. Nature 514: 513-517.

Ortega-Molina A, Boss IW, Canela A, Pan H, Jiang Y, Zhao C, Jiang M, Hu D, Agirre X, Niesvizky I, et al. 2015. The histone lysine methyltransferase KMT2D sustains a gene expression program that represses B cell lymphoma development. Nat Med 21: 1199-1208.

Parsons DW, Li M, Zhang X, Jones S, Leary RJ, Lin JC, Boca SM, Carter H, Samayoa J, Bettegowda C, et al. 2011. The genetic landscape of the childhood cancer medulloblastoma. Science 331: 435-439.

Pasini D, Malatesta M, Jung HR, Walfridsson J, Willer A, Olsson L, Skotte J, Wutz A, Porse B, Jensen ON, et al. 2010. Characterization of an antagonistic switch between histone $\mathrm{H} 3$ lysine 27 methylation and acetylation in the transcriptional regulation of Polycomb group target genes. Nucleic Acids Res 38: 4958-4969.

Pasqualucci L, Trifonov V, Fabbri G, Ma J, Rossi D, Chiarenza A, Wells VA, Grunn A, Messina M, Elliot O, et al. 2011. Analysis of the coding genome of diffuse large Bcell lymphoma. Nat Genet 43: 830-837.

Pirrotta V. 1998. Polycombing the genome: PcG, trxG, and chromatin silencing. Cell 93: 333-336.

Piunti A, Shilatifard A. 2016. Epigenetic balance of gene expression by Polycomb and COMPASS families. Science 352: aad 9780.

Poux S, Horard B, Sigrist CJ, Pirrotta V. 2002. The Drosophila trithorax protein is a coactivator required to prevent re-establishment of polycomb silencing. Development 129: $2483-2493$.

Pugh TJ, Weeraratne SD, Archer TC, Pomeranz Krummel DA, Auclair D, Bochicchio J, Carneiro MO, Carter SL, Cibulskis K, Erlich RL, et al. 2012. Medulloblastoma exome sequencing uncovers subtype-specific somatic mutations. Nature 488: 106-110.

Rada-Iglesias A, Bajpai R, Swigut T, Brugmann SA, Flynn RA, Wysocka J. 2011. A unique chromatin signature uncovers early developmental enhancers in humans. Nature 470: $279-283$

Roguev A, Schaft D, Shevchenko A, Pijnappel WW, Wilm M, Aasland R, Stewart AF. 2001. The Saccharomyces cerevisiae Set1 complex includes an Ash2 homologue and methylates histone 3 lysine 4. EMBO J 20: 7137-7148.

Ruault M, Brun ME, Ventura M, Roizes G, De Sario A. 2002. $M L L 3$, a new human member of the TRX/MLL gene family, maps to $7 \mathrm{q} 36$, a chromosome region frequently deleted in myeloid leukaemia. Gene 284: 73-81.

Schneider J, Wood A, Lee JS, Schuster R, Dueker J, Maguire C, Swanson SK, Florens L, Washburn MP, Shilatifard A. 2005. Molecular regulation of histone $\mathrm{H} 3$ trimethylation by COMPASS and the regulation of gene expression. $\mathrm{Mol}$ Cell 19: 849-856.

Schultz J, Milpetz F, Bork P, Ponting CP. 1998. SMART, a simple modular architecture research tool: Identification of signaling domains. Proc Natl Acad Sci 95: 5857-5864.

Sedkov Y, Benes JJ, Berger JR, Riker KM, Tillib S, Jones RS, Mazo A. 1999. Molecular genetic analysis of the Drosophila trithorax-related gene which encodes a novel SET domain protein. Mech Dev 82: 171-179.
Shilatifard A. 2012. The COMPASS family of histone H3K4 methylases: Mechanisms of regulation in development and disease pathogenesis. Аnnu Rev Biochem 81: 65-95.

Smith E, Shilatifard A. 2014. Enhancer biology and enhanceropathies. Nat Struct Mol Biol 21: 210-219.

Smith ER, Lee MG, Winter B, Droz NM, Eissenberg JC, Shiekhattar R, Shilatifard A. 2008. Drosophila UTX is a histone H3 Lys27 demethylase that colocalizes with the elongating form of RNA polymerase II. Mol Cell Biol 28: 1041-1046.

Stassen MJ, Bailey D, Nelson S, Chinwalla V, Harte PJ. 1995. The Drosophila trithorax proteins contain a novel variant of the nuclear receptor type DNA binding domain and an ancient conserved motif found in other chromosomal proteins. Mech Dev 52: 209-223.

Sur IK, Hallikas O, Vaharautio A, Yan J, Turunen M, Enge M, Taipale M, Karhu A, Aaltonen LA, Taipale J. 2012. Mice lacking a $M y c$ enhancer that includes human SNP rs6983267 are resistant to intestinal tumors. Science 338: $1360-1363$.

Tan J, Ong CK, Lim WK, Ng CC, Thike AA, Ng LM, Rajasegaran V, Myint SS, Nagarajan S, Thangaraju S, et al. 2015. Genomic landscapes of breast fibroepithelial tumors. Nat Genet 47: 1341-1345.

Tkachuk DC, Kohler S, Cleary ML. 1992. Involvement of a homolog of Drosophila trithorax by 11q23 chromosomal translocations in acute leukemias. Cell 71: 691-700.

Tschiersch B, Hofmann A, Krauss V, Dorn R, Korge G, Reuter G. 1994. The protein encoded by the Drosophila position-effect variegation suppressor gene $\mathrm{Su}(\mathrm{var}) 3-9$ combines domains of antagonistic regulators of homeotic gene complexes. EMBO J 13: 3822-3831.

Van der Meulen J, Sanghvi V, Mavrakis K, Durinck K, Fang F, Matthijssens F, Rondou P, Rosen M, Pieters T, Vandenberghe P, et al. 2015. The H3K27me3 demethylase UTX is a gender-specific tumor suppressor in T-cell acute lymphoblastic leukemia. Blood 125: 13-21.

van Haaften G, Dalgliesh GL, Davies H, Chen L, Bignell G, Greenman C, Edkins S, Hardy C, O’Meara S, Teague J, et al. 2009. Somatic mutations of the histone H3K27 demethylase gene UTX in human cancer. Nat Genet 41: 521523.

van Nuland R, Smits AH, Pallaki P, Jansen PW, Vermeulen M, Timmers HT. 2013. Quantitative dissection and stoichiometry determination of the human SET1/MLL histone methyltransferase complexes. Mol Cell Biol 33: 2067-2077.

Waddell N, Pajic M, Patch AM, Chang DK, Kassahn KS, Bailey P, Johns AL, Miller D, Nones K, Quek K, et al. 2015. Whole genomes redefine the mutational landscape of pancreatic cancer. Nature 518: 495-501.

Wang P, Lin C, Smith ER, Guo H, Sanderson BW, Wu M, Gogol M, Alexander T, Seidel C, Wiedemann LM, et al. 2009. Global analysis of H3K4 methylation defines MLL family member targets and points to a role for MLL1mediated H3K4 methylation in the regulation of transcriptional initiation by RNA polymerase II. Mol Cell Biol 29: 6074-6085.

Wang JK, Tsai MC, Poulin G, Adler AS, Chen S, Liu H, Shi Y, Chang HY. 2010. The histone demethylase UTX 
enables RB-dependent cell fate control. Genes Dev 24: 327-332.

Wu M, Wang PF, Lee JS, Martin-Brown S, Florens L, Washburn M, Shilatifard A. 2008. Molecular regulation of H3K4 trimethylation by Wdr82, a component of human Set1/COMPASS. Mol Cell Biol 28: 7337-7344.

Zentner GE, Tesar PJ, Scacheri PC. 2011. Epigenetic signatures distinguish multiple classes of enhancers with distinct cellular functions. Genome Res 21: 12731283.

Zhang J, Dominguez-Sola D, Hussein S, Lee JE, Holmes AB, Bansal M, Vlasevska S, Mo T, Tang H, Basso K, et al. 2015. Disruption of KMT2D perturbs germinal center B cell development and promotes lymphomagenesis. Nat Med 21: 1190-1198.

Zhu J, Sammons MA, Donahue G, Dou Z, Vedadi M, Getlik M, Barsyte-Lovejoy D, Al-awar R, Katona BW, Shilatifard A, et al. 2015. Gain-of-function p53 mutants co-opt chromatin pathways to drive cancer growth. Nature 525: 206-211.

Ziemin-van der Poel S, McCabe NR, Gill HJ, Espinosa R 3rd, Patel Y, Harden A, Rubinelli P, Smith SD, LeBeau MM, Rowley JD, et al. 1991. Identification of a gene, $M L L$, that spans the breakpoint in 11q23 translocations associated with human leukemias. Proc Natl Acad Sci 88: 1073510739 . 


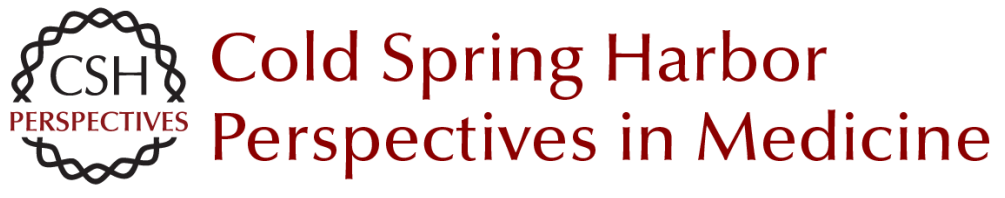

\section{MLL3/MLL4/COMPASS Family on Epigenetic Regulation of Enhancer Function and Cancer}

Christie C. Sze and Ali Shilatifard

Cold Spring Harb Perspect Med 2016; doi: 10.1101/cshperspect.a026427 originally published online September 16, 2016

\section{Subject Collection Chromatin Deregulation in Cancer}

Mixed-Lineage Leukemia Fusions and Chromatin

in Leukemia

Andrei V. Krivtsov, Takayuki Hoshii and Scott A. Armstrong

Targeting Cancer Cells with BET Bromodomain Inhibitors

Yali Xu and Christopher R. Vakoc

The Role of Nuclear Receptor-Binding SET

Domain Family Histone Lysine Methyltransferases

in Cancer

Richard L. Bennett, Alok Swaroop, Catalina Troche, et al.

SETting the Stage for Cancer Development:

SETD2 and the Consequences of Lost Methylation Catherine C. Fahey and lan J. Davis

ATRX and DAXX: Mechanisms and Mutations Michael A. Dyer, Zulekha A. Qadeer, David Valle-Garcia, et al.

DNMT3A in Leukemia Lorenzo Brunetti, Michael C. Gundry and Margaret A. Goodell

Oncogenic Mechanisms of Histone H3 Mutations Daniel N. Weinberg, C. David Allis and Chao Lu

Nonhistone Lysine Methylation in the Regulation of Cancer Pathways

Scott M. Carlson and Or Gozani
TET2 in Normal and Malignant Hematopoiesis

Robert L. Bowman and Ross L. Levine

Long Noncoding RNAs: At the Intersection of Cancer and Chromatin Biology Adam M. Schmitt and Howard Y. Chang

DNA Hypomethylating Drugs in Cancer Therapy Takahiro Sato, Jean-Pierre J. Issa and Patricia Kropf

The Chromodomain Helicase DNA-Binding Chromatin Remodelers: Family Traits that Protect from and Promote Cancer Alea A. Mills

Exploitation of EP300 and CREBBP Lysine Acetyltransferases by Cancer Narsis Attar and Siavash K. Kurdistani

Histone Lysine Demethylase Inhibitors Ashwini Jambhekar, Jamie N. Anastas and Yang Shi

Cohesin Mutations in Cancer Magali De Koninck and Ana Losada

MLL3/MLL4/COMPASS Family on Epigenetic Regulation of Enhancer Function and Cancer Christie C. Sze and Ali Shilatifard

For additional articles in this collection, see http://perspectivesinmedicine.cshlp.org/cgi/collection/ 